\title{
4. Parental rights in education under international law: nature and scope
}

Roman Zinigrad

\section{INTRODUCTION}

The parental right to influence or control their children's instruction is guaranteed by all major human rights instruments that address education (the parental right in international law is, henceforth, the Parental Right, or Right). This guarantee reflects the essential role that parental involvement in education plays in the development and formation of children, in the thriving of their community and their state, and in the parents' own self-fulfillment. Interpreting the Parental Right - i.e., the nature of the obligations it confers on the state, as well as in relation to the right of the child to receive education - is therefore, understandably, a matter of vigorous disputes given the acute ideological disagreement over the best educational means, conditions, and ends.

The stakes in the recognition of the Parental Right are high. Many issues crucially depend on the parental share in designing the curriculum and the learning environment for the state's children today (and constituency tomorrow), including: the strength of a state's democratic institutions, its respect of freedom of thought and other human rights, its degree of tolerance and social cohesion, its economic policies, or its cultural and/or religious minorities' abilities to preserve their identity and defend their interests.

What renders the interpretation of the Right even more challenging are several factors related to the historical transformations in the perception of education, and the special characters of the Parental Right and of the child's right to education. These include: the growing recognition of the child as the main beneficiary of educational rights; the paradigm shift in the conceptualization of parental authority over children; the Right's exceptionality in granting one individual significance over the future of 
another (under established international law children do not have agency to independently determine their education).

In the face of these challenges, this chapter contributes to the understanding of the Parental Right and of the international law framework in which it operates. It describes the debates and predominant interpretations of the nature and of the scope of the Parental Right. Section I discusses the nature of the Parental Right, examining its possible interpretations as a negative or a partially positive; Section II addresses the Parental Right's scope in public and private educational institutions.

\section{THE NATURE OF THE PARENTAL RIGHT}

This section considers whether the Right involves positive obligations on the part of the state. An individual right may be envisioned as one of three options - either entailing material state support to ensure its realization (positive claim), as only requiring the state to guarantee its exercise without interference (negative claim), or as merely allowing the individual to act upon it unless restricted by the state (privilege). ${ }^{1}$ The currently predominant view adopts the second option and considers the state to have a duty to guarantee non-interference in the parental educational choices. While not stated explicitly, this view draws mainly on the unusual language used in some provisions that establish the Right in human rights instruments. It is rooted in the liberal tradition of envisioning rights as ensuring protection from the state rather than assistance, and reflects fears of parental choices that would be detrimental to the child's education and of diverting state resources to private educational institutions at the expense of the public system of education.

But this approach is not without contestation. Supporters of expanded parental choice argue that, without a state obligation to provide financial support to private institutions, the Parental Right is effectively meaningless due to the tremendously burdensome costs of private education. 


\section{A. The Parental Right as a Negative Claim}

Under the currently prevalent interpretation, the Parental Right established in international law should be considered as a negative claim across all international documents and in all instances. ${ }^{2}$ According to this view, states may, but are in no circumstances obligated, to realize the parental educational choices - neither by providing financial support to private education nor even by adding educational elements desired by parents to the public-school curriculum. ${ }^{3}$ For instance, if parents consider that the curriculum is disparaging their culture or not adapted to their religious beliefs, the Parental Right would not be sufficient for parents to demand the change of the state policy.

Indeed, the drafting history of the International Covenant on Economic, Social and Cultural Rights (ICESCR $)^{4}-$ one of the international law instruments framing the Parental Right as a 'liberty' - reveals that the choice of this term in the context of the Parental Right was made with the explicit intention of clarifying that states only have an obligation of non-interference in the parental choice and are not under a duty to support it financially in case parents opt for education in a private school or at home. In the same manner, the European Court of Human Rights (ECtHR or Strasbourg Court) and the European Commission have consistently declared that article 2 of the First Protocol of the European Convention of Human Rights (ECHR art P1-2), ${ }^{5}$ obliging states to guarantee 'the right of parents', does not impose any positive financial obligations on the state, including neither of establishing public nor of subsidizing private education. ${ }^{6}$ Commentaries of other international bodies as well as

2 Under the tripartite classification of state obligations to 'respect, protect, and fulfill' international human rights, negative claims to education constitute the obligation to 'respect'. See, Matthew C.R. Craven, The International Covenant on Economic, Social, and Cultural Rights: A Perspective on Its Development (Oxford University Press 1998) 110.

3 See e.g. Klaus Dieter Beiter, The Protection of the Right to Education by International Law (Martinus Nijhoff 2006) 543.

$4 \quad$ (Adopted 16 December 1966, entered into force 3 January 1976) 993 UNTS 3.

$5 \quad$ Protocol 1 to the European Convention for the Protection of Human Rights and Fundamental Freedoms.

$6 \quad$ See e.g. Belgian Linguistic case (No 2) (1968) 1 EHRR 252 [31]; Kjeldsen v Denmark App No 5095/71 (Commission (Plenary) Decision, 7 December 1976) [152]. 
academic literature mostly share the same understanding, at least in cases when the parents are not members of protected minority groups. While alternately invoking the International Parental Right as either 'right' or 'liberty', they consistently assign them with one and the same meaning of no more, no less than a right of non-interference. ${ }^{7}$ Accordingly, provisions that refer to state obligations in this context are also interpreted as ensuring that parents can make the educational choice but not as assisting them to actually realize that education. ${ }^{8}$ Parents may therefore, at their own expenses, pay for a private education that would conform to their choices. The states' obligation to 'respect' the Parental Right, as framed in ICESCR, the International Covenant on Civil and Political Rights (ICCPR), ${ }^{9}$ the Convention on the Rights of the Child (CRC), ${ }^{10}$ ECHR, ${ }^{11}$ or in the UNESCO Convention against Discrimination in Education (CADE) ${ }^{12}$ is understood as a duty to 'to avoid measures that hinder or prevent the enjoyment of the right'. ${ }^{13}$ These prohibited measures include

$7 \quad$ On the general Parental Right in art 18(4) ICCPR, see e.g. Manfred Nowak, U.N. Covenant on Civil and Political Rights: CCPR Commentary (2nd edn, NP Engel 2005) 433-34; Blom v Sweden Communication No 191/1985, UN Doc CCPR/C/OP/2 [10.3]; Sharon Detrick, A Commentary on the United Nations Convention on the Rights of the Child (Martinus Nijhoff 1999) 521; Luzius Wildhaber, 'Right to Education and Parental Rights' in Ronald St. J. MacDonald et al. (eds.), The European System for the Protection of Human Rights (Kluwer Law International 1993) 533. But see the exception of positive Parental Rights in art 26 ICCPR, below.

8 The distinction between negative and positive state protection is arbitrary as even ensuring interference requires allocation of resources, and the case of education is no exception to this observation. See e.g. Patrick Thornberry, International Law and the Rights of Minorities (Clarendon Press 1993) 181-2.

$9 \quad$ (Adopted 16 December 1966, entered into force 23 March 1976) 999 UNTS 171 .

10 (Adopted 20 November 1989, entered into force 2 September 1990) 1577 UNTS 3.

11 Convention for the Protection of Human Rights and Fundamental Freedoms (European Convention on Human Rights, as amended).

12 (Adopted 14 December 1960, entered into force 22 May 1962) 429 UNTS 93.

13 CESCR 'General Comment 13: The Right to Education (art 13)' (8 December 1999) UN Doc E/C.12/1999/10 [47]. See also, Fons Coomans, 'Content and Scope of the Right to Education as a Human Right and Obstacles to Its Realization' in Yvonne Donders and Vladimir Volodin (eds.), Human Rights in Education, Science, and Culture: Legal Developments and Challenges (Ashgate 2007) 187, 189. 
such actions as the prohibition of private religious education, the refusal to adapt the public-school curriculum to parental religious or moral convictions, or a refusal to exempt children from specific curricular contents. ${ }^{14}$

The theoretical grounds for this reading of the Parental Right are found in the liberal tradition that perceives rights as checks on government power that guarantee protection from incursion upon personal freedoms, rather than material support in the rights' realization. In this reading, the Right is therefore perceived as what is sometimes (misleadingly) labeled a 'first generation' right. The pragmatic rationale for supporting this negative interpretation is mainly twofold. First, it is the presumption that the Parental Right is dangerously prone to compromising the child's right to education due to the risk that parents will choose educational institutions or contents of inferior quality to that chosen by the public system. Given this characterization, the denial of public funds (or of introduction of parental choices into the public-school curriculum) functions as a strong disincentive for parents to disagree with the state's educational ideology. ${ }^{15}$ Second, the apprehension that investment in private educational institutions will drain the resources essential for the public system creates a presumption against material support of parental choices. ${ }^{16}$

$14 \quad$ See e.g. Kjeldsen (n 6) [153], [158]; Campbell v. UK (1982) 4 EHRR 293 [37]; Coomans (n 13) 189-90.

15 See e.g. Stephen G. Gilles, 'On Educating Children: A Parentalist Manifesto' (1996) 63 U Chi L Rev 937, 942 ('Selective funding [where only public schools receive government funding] exerts powerful - and highly questionable - financial pressure on dissenting parents to conform their educational choices to the majority's values by enrolling their children in public schools to avoid the heavy burden of private school tuition'); Moshe Cohen-Eliya and Yoav Hammer, 'An Argument from Democracy against School Choice: A Critique of Zelman v. Simmons-Harris' (2003) 49 Loy L Rev 859, 902 ('A lack of funding for private schools increases the relative cost of education in such schools compared with the cost of public school education. As a result, the number of pupils attending private schools - some of which, as aforesaid, do not teach democratic values - should decrease. In this manner it would be possible to ensure that most students are taught democratic values within public schools'). See also Harry Judge, 'Faith-Based Schools and State Funding: A Partial Argument' (2001) 27 Oxf Rev Educ 463, 469-70.

16 See e.g. Jerry Paquette, 'Public Funding for "Private" Education: The Equity Challenge of Enhanced Choice' (2005) 111 Am J Educ 568, 582 ('In the current conjuncture of globalization, restraint, and retrenchment, the proposition that public funding for private schools will have a negative impact on funding for public schools seems difficult to refute. At the very least, all other things being 
The interpretation of the Parental Right as a negative claim is, however, subjected to criticism on both fronts, as being either too narrow or too broad. The following subsection discusses the first alternative of reading the Right as a partially positive claim.

\section{B. The Parental Right as a Limited Positive Claim}

International law has a long tradition of requiring positive support from the state for minority education. The Treaty Between the Principal Allied and Associated Powers and Poland, 1919 is arguably the first international document to write educational rights into international law. The treaty established that minorities constituting a considerable proportion of a Polish town or district 'shall be assured an equitable share in $[\ldots]$ the sums which may be provided out of public funds under the State $[. .$.$] for$ educational $[\ldots]$ purposes,' thus explicitly defining the minorities' right to choose education as a positive claim, albeit under a regime predating the United Nations.

Today, the strongest backing for defining the Parental Right as requiring the state to provide their children the education of their choice arises for parents belonging to protected minority groups, and especially so to indigenous peoples. But support in international law is found also for a general state obligation to fund private education as long as it is subject to a list of rigorous regulations. Positive readings of the Parental Right as an instrument that guarantees equality in education to minorities appear in ICCPR, ICESCR, and CADE, with the most explicit assertion being stated in the International Labour Organization (ILO Convention) 169. ${ }^{17}$

Article 27(3) of the Convention, which recognizes the right of indigenous and tribal peoples to "establish their own educational institutions and facilities, provided that such institutions meet minimum stand-

equal (notably revenues and political will to spend), such funding adds a new spending focus to already thinly stretched state or provincial budgets with the result that the political valence of an average budget line must increase to maintain the current funding level for it. Given this addition, all other things being equal, the public education envelope could be expected either to lose funding or, in the best-case scenario, to have its current rate of increase reduced. In short, the often repeated claim that public funding for private schools 'is from a different pot' and does not negatively impact educational funding is disingenuous').

17 Convention concerning Indigenous and Tribal Peoples in Independent Countries (1989) (ILO Convention No. 169) (adopted 27 June 1989, entered into force 5 September 1991) 328 UNTS 247. 
ards established by the competent authority in consultation with these peoples', also requires the state to ensure that '[a]ppropriate resources shall be provided for this purpose'. This Article explicitly entitles the peoples protected by the Convention to claim material support from the state in establishing autonomous, non-state educational institutions, in contrast to the remarkable absence in many other analyses and debates on the international obligations of states regarding private education. While not directly referencing the Parental Right, this provision clearly concerns parents who choose to send their children to the school managed by their own communities. ${ }^{18}$

Another normative source that assigns the Parental Right positive features is article 27 ICCPR, which states 'persons belonging to [ethnic, religious or linguistic] minorities shall not be denied the right [...] to enjoy their own culture, to profess and practise their own religion, or to use their own language'. Article 27 does not explicitly mention the Parental Right but that article's provision has been consistently interpreted to include the right of parents to pass their identity on to their children through education. And while article 27 has been initially formulated as to constitute only a duty of non-interference - hence the text's negative formulation that the right 'shall not be denied' - several sources suggest that the Parental Right in article 27 should be interpreted as a positive claim.

Principal among these sources is General Comment 23 of the Human Rights Committee (HRC), stating that the enjoyment of all rights guaranteed under article 27 depends on the ability of the protected minority groups to maintain their way of life, and that to this end 'positive measures by States may also be necessary to protect the identity of a minority and the rights of its members to enjoy and develop their culture and language and to practise their religion'. ${ }^{19}$ The HRC's assertion implies that at least in those cases where education proves to be an essential tool for the preservation of a minority's identity, the state should be obligated to provide the necessary means that will guarantee the according education of minority children.

18 See also, International Labour Standards Department, Indigenous and Tribal Peoples' Rights in Practice: A Guide to ILO Convention No. 169 (2009) 131.

19 UNCHR 'General Comment 23: Article 27 (Rights of Minorities)' (8 April 1994) UN Doc CCPR/C/21/Rev.1/Add.5 [6.2]. 
This issue was addressed in the Waldman case, which concerned the funding of denominational schools in the Canadian province of Ontario, where some religious schools were granted partial, indirect financial support from the state, but other schools via a special legal status had direct, full public funding. ${ }^{20}$ The HRC decision found such differential treatment to violate article 26 ICCPR, which prohibits discrimination on the grounds of religion. However, Martin Scheinin, a member of the HRC, concurred adding a separate analysis of how article 27 impacted the case. In Scheinin's view, where a 'sufficient number' of minority parents considers secular public schools to be incompatible with their views and demands to provide their children with religious (or linguistic) instruction, the state can choose to either establish a public school that would answer their expectations or allocate equal resources to a private school, but doing neither would amount to discrimination. Both choices in any event require positive financial assistance to minority groups and are requisite because "Article 27 imposes positive obligations for States to promote religious instruction in minority religions' ${ }^{21}$ And while the application of Scheinin's criterion must face the challenge of estimating how many parents are required to constitute this state obligation, his opinion is important for the very recognition of the possibility to do so.

Read together, General Comment 23 and Scheinin's view provide that the Parental Right in article 27 guarantees children belonging to protected minority groups an education that is state-funded and adapted to the way of life and wishes of their parents, at least when essential for preserving the minority's identity and with enough children to justify opening a separate school for this purpose.

The view that the Parental Right of members of minority groups can constitute a positive state duty was similarly adopted in the application of ICESCR. In 2001, the Committee on Economic, Social and Cultural Rights (CESCR) expressed concern about the inability of minorities in $\mathrm{Japan}^{22}$ to receive education in their language and about their culture within the public system, and the tension it created with the principle of non-discrimination in article 2(2) ICESCR. To address this tension, the Committee recommended that the state recognize the private minority

\footnotetext{
$20 \quad$ Waldman v. Canada (1999) 7 IHRR 368.

$21 \quad$ Ibid, Scheinin M (concurring) [5].

22 This refers to Buraku and Okinawa communities, the indigenous Ainu people, and people of Korean descent.
} 
schools and make funding available. ${ }^{23}$ Unlike Waldman, which involved selective funding of private schools, this matter involved the overall lack of funding of special minority education. This was deemed a form of discrimination in comparison with the Japanese majority in the state. This decision indicates that the Parental Right to choose education other than the default provided by the state is in fact a positive claim if only for members of minority groups. ${ }^{24}$

Furthermore, the interpretation of the Parental Right in article 13(3) in conjunction with article 2(2) ICESCR as casting positive obligations on the state is appropriate despite it being defined as 'liberty', which implies only negative duties. First, the Covenant is rooted in a welfare conception of human rights and was explicitly conceived to guarantee 'second generation' rights through positive state obligations. This background coalesces with the rationale of ensuring the education of minority groups in ICCPR and so reinforces the view of the Right as a positive claim at least under the strict conditions of article 27 ICCPR, delineated above.

The same conclusion follows if one applies a contextual (or systematic) method of interpretation to article 13(3), ${ }^{25}$ and that due to the fact that the Parental Right appears in both ICESCR and ICCPR and is formulated in both Covenants in identical language (in articles 13(3) and 18(4), respectively). ${ }^{26}$ A plausible explanation to resolve this apparent redundancy would be to accredit ICCPR, which protects 'first generation' rights, with

23 CESCR 'Concluding Observations: Japan' (24 September 2001) UN Doc E/C.12/1/Add.67 [60].

24 In its decision, CESCR refers to art 13(2) ICESCR, without explicitly mentioning art 13(3) on the parental liberty. However, since the parental will is the only reason to send children of minority groups in Japan to schools that preserve their identity, the Committee's recommendation clearly requires to interpret the Parental Right - and not only the right of the minority children to receive education - as a positive claim.

25 Contextual interpretation 'is concerned with the innate connexion in which all the institutions and rules of law are bound up into a great unity'. It clarifies 'in what relation [a single legal provision] stands to the entire system of law and it is practically to enter into the system', Friedrich Karl von Savigny, System of the Modern Roman Law (William Holloway tr, 1867). And see Nowak (n 7) XXVI ('Systematic interpretation [of the ICCPR] may also be aided by a comparative analysis of similar human rights conventions, such as the Social Covenant').

26 The contextual approach is the main method of interpretation in international law. See Vienna Convention on the Law of Treaties (adopted May 23, 1969, entered into force 27 January 1980) 1155 UNTS 331 art 31. 
the guarantee of the negative aspect of the Parental Right, and ICESCR, its positive aspect. ${ }^{27}$

Beiter and others also support the joint reading of articles 13(3) and 2(2) ICESCR as generating a positive Parental Right. Their reasoning is that the heavy financial burdens imposed on parents whose convictions do not allow for sending their children to public schools that lack compatible religious or moral education puts them at an unfair disadvantage. ${ }^{28}$ And it has been furthermore suggested that the parental 'liberty'-right in article 13(3) should be interpreted as obligating the state to financially support parental choices not only when parents have ideological disagreements with the public curriculum, but as well in cases of gifted or disabled children, if parents wish to provide them with education that will better meet their needs. ${ }^{29}$

\section{THE SCOPE OF THE PARENTAL RIGHT}

\section{A. Introduction}

Having analyzed the nature of the obligations the Parental Right casts on the state, the following subsection addresses the circumstances to which it applies, the extent of the parental discretion in education, and the external constraints on this discretion. These elements define the scope of the parental prerogative to decide what and how their child should learn and determine what level of control parents have over the contents, methods, and organization of her education.

The first principle to be deduced from the definition of the Right in international law is that it concerns children's education, and so its scope includes, by definition, only those parental demands that concern a choice of education. Parents therefore cannot choose to deny the child education altogether. The scope of the Parental Right can be defined either by referring to the substance of the child's education, or, indirectly, by reference to the types of educational institutions that can be chosen by her parents. Indeed, international instruments employ both of these options and prescribe the Right's scope in both substantive and institutional terms. Submitting to the same structure, the chapter makes a distinction between

$27 \quad$ See Beiter (n 3) 559-60.

$28 \quad$ Ibid 559-60 and references there.

29 Ibid 560, 566, and references there. 
these two sub-categories of the Parental Right. Importantly, the scope of the substantive element of the Parental Right applies to both public and private educational institutions.

\section{B. Public Education (Substantive Parental Right)}

As opposed to the 'institutional' provisions granting parents the right to choose a non-public school for their child (discussed below), the substantive provisions that address the contents of education are not limited to specific schools. They are equally valid for all institutions - private and public, including institutions run by the state. ${ }^{30}$

Most international and regional instruments, such as ICESCR, ICCPR, the African Charter on the Rights and Welfare of the Child (ACRWC), the American Convention on Human Rights (ACHR), and CADE, limit the scope of the Parental Right to a specific type of instruction, stipulating that parents can only determine the 'religious and moral' education of their children. ${ }^{31}$ Elsewhere provisions use different variations of 'religious and philosophical', ${ }^{32}$ or yet again, 'religious and philosophical and pedagogical' ${ }^{33}$ convictions. Some documents grant parents a general right to choose without qualifying its nature. These latter exceptions may be understood as to refer to education in its broad sense, as encompassing not only religion and morals, but 'the entire process of social life by means of which individuals and social groups learn to develop consciously $[\ldots]$ the whole of their personal capacities, attitudes, aptitudes and knowledge', ${ }^{34}$ and including the transmission of knowledge and the nurturing of intellectual development. ${ }^{35}$ As a rule, the terms 'religious', 'moral', 'philosophical', and 'pedagogical' are interpreted broadly and inclusively.

$30 \quad$ See e.g. ibid 540-59.

$31 \quad$ ICESCR art 13(3); ICCPR art 18(4); African Charter on the Rights and Welfare of the Child (adopted 1 July 1990, entered into force 29 November 1999) OAU Doc CAB/LEG/24.9/49 (1990) art 11(4); American Convention on Human Rights (21 November 1969) 1144 UNTS 143 art 12(4); CADE art 5(1)(b).

32 ECHR art P1-2.

33 CFR art 14(3).

34 UNESCO 'Recommendation Concerning Education for International Understanding, Co-Operation and Peace and Education Relating to Human Rights and Fundamental Freedoms' (19 November 1974) s I.1(a).

35 Campbell (n 14) [33]. 
The term 'religion' remains undefined in international and regional human rights instruments. ${ }^{36}$ HRC's General Comment 22 (GC22) holds that 'religion' should be 'broadly construed' and apply not only to traditional and institutionalized forms of worship but also to "newly established' ones. ${ }^{37}$ Narrower definitions of 'religion' - as founded upon a belief in a higher force or only encompassing 'known religions ${ }^{38}$ - have also been suggested in the literature, and the legal definition of religion has proven to be a contentious concept in domestic caselaw as well. ${ }^{39}$ Notwithstanding the different interpretations of 'religious', the relevant educational provisions always refer to 'religious' only together with 'moral' or 'philosophical' values and so anyway clearly encompassing beliefs that are not validated by a 'Supreme Being', by an already established religious community, or for that matter, any religious authority at all, whatever religion is taken to mean.

The term 'moral' in international instruments, while lacking a clear autonomous definition, is understood to bear the same meaning as the term 'philosophical' in article P1-2, ECHR, ${ }^{40}$ as fleshed out by the ECtHR and the (now obsolete) European Commission on Human Rights. According to the Commission's view in the Campbell case,

36 T. Jeremy Gunn, 'The Complexity of Religion and the Definition of Religion in International Law Conference: Religion, Democracy, \& Human Rights' (2003) 16 Harv Hum Rts J 189, 189-90.

37 UNCHR, 'General Comment 22: Article 18 ICCPR' (30 July 1993) UN Doc CCPR/C/21/Rev.1/Add.4 [2] (note that CESCR's General Comment 13 does not mention the same broad interpretation for ICESCR). Some further suggest the term should include atheistic values, mirroring whatever definition of 'religious' values is accepted, Beiter (n 3) 542 and references there.

38 On the former, Beiter (n 3) 541; on the latter, Ben Saul et al., The International Covenant on Economic, Social and Cultural Rights: Commentary, Cases, and Materials (Oxford University Press 2014) 1152-53. The limitation to 'known' religions seems, however, misguided. Saul and others base their view on ECHR's decision in Valsamis v Greece (1996) 24 EHRR 294 [26], but the Court draws the 'known religion' term from the Greek Constitution and does not use it as a definition of 'religion' in general.

39 See e.g. the changes in the definition of 'religion' in the caselaw of the US Supreme Court, in Samuel J. Levine, 'A Critique of Hobby Lobby and the Supreme Court's Hands-off Approach to Religion Essays' (2015) 91 Notre Dame L Rev Online 26, 34, fn 28.

$40 \quad$ 'No person shall be denied the right to education. In the exercise of any functions which it assumes in relation to education and to teaching, the State shall respect the right of parents to ensure such education and teaching in conformity with their own religious and philosophical convictions.' 
'philosophical' beliefs consist of 'ideas based on human knowledge and reasoning concerning the world, life, society, etc., which a person adopts and professes according to the dictates of his or her conscience' and can be summarized as 'a person's outlook on life'. ${ }^{41}$ Formulating its view as a middle-ground interpretation, the Strasbourg Court added in a like manner that the adjective 'philosophical' in Article 2 is not limited to fully-fledged systems of thought but does exclude 'views on more or less trivial matters'.

The most generous interpretation so far of what constitutes 'philosophical' beliefs was set by the Strasbourg Court concerning the choice of language in which education is provided. Initially, the Court held in the 1968 Belgian Linguistic case that the term 'religious and philosophical convictions' does not cover the parents' linguistic preferences, ${ }^{42}$ but this interpretation was subsequently rejected. In the 2012 Catan case the Court established that philosophical convictions in article P1-2 ECHR do include choice of language if it is one of the state's national languages, and ruled that parents have the right to ensure that the private education of their child is provided in that national language..$^{43}$ Additionally, as shown below, although the circumstances of the case concerned only private schools, the said provision applies also to public education. ${ }^{44}$ And finally, since the limitation of parental convictions to 'parental and philosophical' appears only in article P1-2 ECHR, the recognition of linguistic choices as part of the Parental Right is even more natural and evident for provisions like article 13(3) ICESCR, whose phrasing can better accommodate linguistic convictions. ${ }^{45}$ Furthermore, due to this

$41 \quad$ Campbell and Cosans v United Kingdom Series B no 42 (Commission Opinion, 16 May 1980) 37.

$42 \quad$ Belgian Linguistic case (n 6) [6].

$43 \quad$ Catan v Moldova and Russia (2013) 57 EHRR 4 [137], [143]. See also Cyprus v Turkey (2002) 35 EHRR 30 [278], [280], where the Court ruled that the Turkish-Cypriot authorities violated ECHR art P1-2 by abolishing secondary Greek-language schools in northern Cyprus and consequently leaving Greek-Cypriot children who have already pursued primary education in Greek without appropriate secondary-school facilities (but note that the infringement of educational rights in this case was rooted in the difficulty to switch the language of learning rather than the right to be educated according to the parents' convictions). For a comprehensive analysis of the language aspect of the right to education see Jacqueline Mowbray, Linguistic Justice: International Law and Language Policy (Oxford University Press 2012) 28-50.

$44 \quad$ Catan (n 43) para 139; Kjeldsen (n 6) [50].

45 See in the same spirit, Saul and others (n 38) 1137-38. 
general phrasing, article 13(3) ICESCR can be interpreted as including even linguistic preferences of languages other than national.

Article 14(3) of the Charter of Fundamental Rights of the European Union (CFR) adds 'pedagogical' convictions to that which must be considered. The CFR explanatory notes provide only that article 14(3) was based on article P1-2 ECHR, ${ }^{46}$ leading some to suggest that the scope of the Parental Right under both articles is identical. ${ }^{47}$ Following this narrative the addition of the 'pedagogical' element may be possibly interpreted as the codification of previous rulings of the ECtHR, such as that the scope of the Right includes opposition to corporal punishment in schools. ${ }^{48}$ A less 'originalist' reading of article 14(3) should, however, lead to the conclusion that the new addition represents a distinct category of convictions parents can consider in ensuring the education of their children. I suggest that one option to differentiate pedagogical convictions from religious and philosophical ones is to consider that parents can oppose public school policies based on pedagogical methods or recent research findings in this field yet to be adopted by the state educational system.

As to the meaning of 'convictions' (outlined below) based on which parents are authorized to control the education of their child, the ECtHR held that it is "not synonymous with the words "opinions" and "ideas" $[\ldots]$ and denotes views that attain a certain level of cogency, seriousness, cohesion and importance'. ${ }^{49}$ Thus, for instance, opposition to administering corporal punishment on children was classified by the ECtHR in the Campbell case as a 'conviction' because it was based upon views relating to 'a weighty and substantial aspect of human life and behavior, namely the integrity of the person, the propriety or otherwise of the infliction of corporal punishment and the exclusion of the distress which the risk of such punishment entails'. ${ }^{50}$

The Substantive Parental Right applies not only to the contents of a child's education but also to the educational methods and means the school employs, as well as the school's general organization. In public

46 Draft Charter of Fundamental Rights of the European Union - Text of the Explanations Relating to the Complete Text of the Charter as Set out in Charte 4487/00 Convent 50.

$47 \quad$ Beiter (n 3) 196-97.

$48 \quad$ Campbell (n 14). And see below.

49 Ibid [36].

50 Ibid. 
schools, therefore, the state is to account for the parental convictions in decisions regarding such topics as: the use of disciplinary means, like corporal punishment; ${ }^{51}$ the display of religious symbols, like crucifixes, in classrooms, ${ }^{52}$ or the organization of school parades commemorating wars. ${ }^{53}$ The relatively broad interpretation of the above provisions is, however, limited by the following substantive and technical restrictions.

The first substantive limitation on the Right deriving from the above provisions is set in light of the fundamental values of the international and regional instruments that protect it. Interpreting the ECHR, the Strasbourg Court has held that 'philosophical convictions' encompass nothing but beliefs that are 'worthy of respect in a 'democratic society' [, ...] not incompatible with human dignity [and not conflicting] with the fundamental right of the child to education'.$^{54}$ This constraint is valid also for the term 'moral' in article 13(3) ICESCR and other similar provisions, in virtue of the analogy between them and ECHR article P1-2. Indeed, the travaux préparatoires of ICESCR reflect the same restrictions on the meaning of 'moral' beliefs. Drafts of article 13(3) ICESCR initially referred to 'philosophical', instead of 'moral' education with the use of the latter eventually prevailing only to emphasize that the parental right does not extend to extreme views that might undermine the state's role in protecting the interests of the child in education..$^{55}$

Second, if the public-school education provided to children seeks to expose children to new information and ways of thinking rather than aiming to subvert the parental values, it is not considered to infringe upon the Parental Right. Thus, according to the ECtHR, public schools can directly or indirectly expose children to religious and moral values even if they contradict the convictions of their parents, as long as the school does not seek to indoctrinate the child into these values and remains impartial as to their validity. ${ }^{56}$ Similarly, GC22 allows for "neutral and

$51 \quad$ Campbell (n 14).

$52 \quad$ Lautsi v Italy (2011) 54 EHRR 3 [63]. The Court, however, ended up not prohibiting this practice in Italian schools citing the doctrine of the margin of appreciation.

$53 \quad$ Valsamis v Greece (1996) 24 EHRR 294 [27]; Efstratiou v Greece App No 24095/94 (ECtHR, 18 December 1996) [28]. In these cases too, however, the Court found the particular school policy not to violate the Parental Right.

$54 \quad$ Campbell (n 14) [36].

$55 \quad$ See Beiter (n 3) and references there.

56 See e.g. Kjeldsen ( $\mathrm{n}$ 6) [53]; Appel-Irrgang $v$ Germany App No 45216/07 (ECtHR, 6 October 2009). 
objective' education, ${ }^{57}$ and $\mathrm{GC} 13$ asserts that article 13(3) ICESCR permits 'public school instruction [...] if it is given in an unbiased and objective way, respectful of the freedoms of opinion, conscience and expression'. ${ }^{58}$ In this spirit, the HRC found that the Parental Right of atheist parents in Finland, whose children were required by their public school to attend classes in the history of religion and ethics, was not violated by this requirement because they were taught 'in a neutral and objective way'. ${ }^{59}$ And the ECtHR established that sexual education in Danish public schools does not violate the Parental Right when taught in 'an objective, critical and pluralistic manner' ${ }^{60}$

In light of the above, the mandate of public schools should be interpreted broadly as including the option of exposing children not only to neutral or objective facts but also to moral and religious values concerning those facts or other perceptions, even if they stand in direct contradiction with the parental convictions, as long as these are not presented as the only conceivable beliefs children can adopt. That interpretation is also best aligned with the prohibition on the state to pursue an aim of indoctrination that clashes with the parental convictions. ${ }^{61}$

International and regional documents set a list of basic educational goals to which both public and private educational systems must conform. Parents cannot oppose educational contents and activities that pursue these goals within the public-school system, on any grounds, even if they find them objectionable on religious grounds or otherwise biased. ${ }^{62}$

If certain educational elements imposed by a public school are indeed found to violate the Substantive Parental Right under the above provisions, international law entitles the parent to relieve her child from the part of her public-school curriculum that conflicts with her convictions. The Substantive Parental Right does not, however, amount to introducing

$57 \quad \mathrm{GC} 22$ (n 37) [6].

$58 \quad$ GC13 (n 13) [28].

59 Erkki Hartikainen v Finland Communication No 40/1978, UN Doc CCPR/C/12/D/40/1978 [para 10.4].

$60 \quad$ Kjeldsen (n 6) [53]. See similar ruling in Dojan v Germany App no 319/08 (ECtHR, 13 September 2011).

${ }_{61} \quad$ But see the separate opinion of Judge Verdross in Kjeldsen (n 6).

62 For the provisions and interpretation of the core goals, see below, the analysis of the Institutional Parental Right. 
the educational contents preferred by the parent into the public-school curriculum.

In the public system, the Right amounts, at the very least, to exempting the child from some or all of the classes conflicting with the parent's convictions. Thus, non-Christian parents in Norway were found to have the right to fully exempt their children from compulsory class studies in Christianity, religion, and philosophy, because the class curriculum was found to not be conveyed in an 'objective, critical, and pluralistic manner'. ${ }^{63}$ The ECtHR also decided that a father associating himself with the Alevi religious tradition had the right to exempt his daughter from classes on religious culture and ethics in a state school in Turkey, because the classes were shown to provide extensive teaching of Islam but no teaching at all on the Alevi faith, and thus did not meet the criteria of 'objectivity and pluralism' ${ }^{64}$ Finally, the Parental Right of parents in Scotland was sufficient to demand their children are not subjected to corporal punishment by the authorities in the state schools they attended. ${ }^{65}$

The provisions guaranteeing the Substantive Parental Right do not, however, under the current, prevalent interpretation, include the right to include the religious or moral education that accords with the parental convictions within the public-school system. These provisions only create a negative state duty to refrain from instruction that interferes with parental beliefs but do not pose an obligation to integrate those beliefs in the instruction. ${ }^{66}$

Finally, as mentioned, the provisions ensuring the Substantive Parental Right apply not only to public but to private education, where they guarantee state non-interference in the choice of the private school, and state protection against interference on behalf of third parties. For instance, forced closure of private schools that provide education in one of the state's national languages, as well as harassment and intimidation of those interested to attend them, amounts to a violation of the Substantive Parental Right in ECHR article P1-2, ${ }^{67}$ and in similar provisions.

$63 \quad$ Folgerø and Others v Norway (2008) 46 EHRR 47 [102].

64 Zengin v Turkey App No 1448/04 (ECtHR, 9 October 2007) [63]-[65].

65 Campbell (n 14) [37]-[38].

66 On the potential positive attributes of the Substantive Parental Right, see above.

$67 \quad$ Catan (n 43) [143]. 


\section{Private Education (Institutional Parental Right)}

In addition to the Substantive Parental Right, international law grants parents the prerogative to opt out from the system of public education and choose to send their children to a private educational institution not managed by the state. This Institutional Parental Right is guaranteed explicitly by instruments such as ICESCR and ACRWC and is tacitly inferred also from general provisions in other international and regional instruments concerning the Parental Right. Thus, the travaux préparatoires of article 26(3) UDHR, ${ }^{68}$ which provides generally for a (prior) parental right 'to choose the kind of education that shall be given' to the child, indicate that the provision was intended to include the right to choose not only the contents of education but also in which school they are to be provided.$^{69}$ Even more importantly, the ECHR, which mentions in article P1-2 only the 'right of parents to ensure [...] education and teaching in conformity with their own religions and philosophical convictions' and lacks the element of school choice that appears in ICESCR, is nevertheless interpreted by the Strasbourg Court as including both the Substantive and the Institutional Parental Rights. ${ }^{70}$

The distinction made in international instruments between the right to choose a private school and a right to ensure the child's education in accordance with the parent's convictions implies that the scope of the institutional aspect of the Parental Right is - while not unlimited considerably more extensive than its substantive element, in terms of parental discretion. Had the goal been to allow parents the same degree of control in both public and private institutions, the educational provisions could suffice with introducing the Substantive Parental Right that would apply to all types of educational institutions. The Right to opt for private education entails therefore the prerogative to choose educational contents

\footnotetext{
68 Universal Declaration of Human Rights (adopted 10 December 1948) UNGA Res 217 A(III).

69 See e.g. UN Doc E/CN.4/SR.68 in William A Schabas, The Universal Declaration of Human Rights: The Travaux Préparatoires (CUP 2013) 1849, 1851-52. See also Beiter (n 3) 93. For similarly worded provisions, see e.g. Additional Protocol to the American Convention on Human Rights in the Area of Economic, Social and Cultural Rights (Protocol of San Salvador) (adopted 17 November 1988, entered into force 16 November 1999) OAS Treaty Series No 69 (1988) art 13(4).

$70 \quad$ See e.g. Kjeldsen (n 6) [50]; Folgerø (n 62) [84(b)].
} 
and methods that 'differ substantially' from the public-school curriculum. ${ }^{71}$ The parental choice may therefore regard religious schools as well as secular alternatives to public education such as anthroposophic, democratic, or Montessori schools.

The scope of the Parental Right - and the consequent freedom of private educational institutions - is, however, not unlimited only in virtue of their separation from the public system. International law curbs the scope of the Institutional Parental Right by two types of 'external' constraints - ad international law and ad domestic state law. Both types concern the minimal requirements even private schools must pursue, in virtue of those interests of children and the state that conflict with the Parental Right.

The first 'external' limitation on the Institutional Parental Right is embodied by the goals of education, enshrined in international and regional documents as an essential component, 'a most basic form, ${ }^{72}$ of the child's right to education. The educational goals apply to all types and levels of education and so (directly or indirectly) bind all actors in the realm of education, including the parents, the state, and individuals or entities managing private educational institutions. Ensuring that education conforms to these goals is also considered to be part of what has been characterized as the 'minimum core obligations' the state is obligated to fulfill irrespective of the availability of its resources or other difficulties. ${ }^{73}$ The list of these core educational goals appears with

Beiter (n 3) 539.

GC13 (n 13) [57].

CESCR 'General Comment 3: The Nature of States Parties' Obligations' (14 December 1990) UN Doc E/1991/23 [10]; GC13 (n 13) [57]; 'The Maastricht Guidelines on Violations of Economic, Social and Cultural Rights' (1998) 20 Hum Rights Q 691, 695; Coomans (n 13) 207. 
some variations in the UDHR, ${ }^{74}$ ICESCR $,{ }^{75} \mathrm{CRC},{ }^{76}$ the Protocol of San Salvador, ${ }^{77}$ the ACRWC,${ }^{78}$ and other instruments. ${ }^{79}$

As to normative hierarchy between the obligation to implement the core educational goals and the Institutional Parental Right, in case of a clash between the two the former prevails over the latter. ${ }^{80}$ This hierarchy seems, however, to be valid only if the clash is clear and cannot be avoided by means of interpretation. The nature of the educational goals as framed in international instruments, particularly in ICESCR, as well as the autonomous status of the Parental Right, suggests that the goals should be interpreted to align as much as possible with the parental educational preferences. Considering the absence of detailed guidelines or unison as to the meaning of some of the educational goals, the relatively mild ratification of the goals in international instruments, and the status of the Parental Right as an autonomous human right, the 'specific formal endorsement' of the goals should accommodate the parental choices of private education.

The second 'external' limitation imposed on the scope of the Institutional Parental Right addresses the role and interests of the state in education, thus balancing the counter-state motivations that give rise to the abovementioned core goals of education. It is manifested in international and regional instruments by further restricting the parental choice of private schools solely to institutions that conform to educational standards set by the state. To disperse any doubts, some documents even

Art 26(2) ('Education shall be directed to the full development of the human personality and to the strengthening of respect for human rights and fundamental freedoms. It shall promote understanding, tolerance and friendship among all nations, racial or religious groups, and shall further the activities of the United Nations for the maintenance of peace').

$75 \quad$ Art 13(1).

$76 \quad$ Art 29(1).

$77 \quad(\mathrm{~N} 68)$ art 13(2).

78 Art 11(2).

79 See e.g. WCEFA, World Declaration on Education for All: Meeting basic learning needs (1990) art I; Vienna Declaration and Programme of Action, UN World Conference on Human Rights (25 June 1993) UN Doc A/ CONF.157/23 [I.33], [II.80]; Plan of Action for the United Nations Decade for Human Rights Education, 1995-2004 (12 December 1996) UN Doc A/51/506/ Add.1 pt II.

${ }_{80} \quad$ See e.g. GC13 (n 13) [6(c)]. 
reiterate this precondition as an additional and separate restriction on the right to establish private educational institutions. ${ }^{81}$

The enactment by the state of educational standards in relation to private education is framed in some international provisions as a discretionary power but has been interpreted even in those provisions as a duty that the state cannot forbear. Thus, the provision of article 13(4) ICESCR that 'education given in [non-state] institutions shall conform to such minimum standards as may be laid down by the State', ${ }^{82}$ is understood in $\mathrm{GC} 13$ to mean that the state is 'obliged to establish "minimum educational standards", and furthermore, that it 'must also maintain a transparent and effective system to monitor such standards'. ${ }^{83}$

The state's control over private education does have limits. First, since the state itself is subjected to the international law requirements concerning the goals of education discussed above, the educational standards it lays down for private institutions must be in compliance with these goals and cannot require private schools to violate them. The core goals of education, such as enabling 'all persons to participate effectively in a free society', and promoting 'understanding, tolerance and friendship', also include the civic values essential for the state to preserve its stability and perpetuate the successful functioning of its institutions that must therefore be introduced to children even against parental disagreement.

Second, as seen above, according to article 13(3) ICESCR and other instruments, the power to circumscribe the parental choice applies only to the setting of 'minimum educational standards'. This clearly implies that the regulation of private education must be lower than the requirements made by the state for the system of public education. The rationale of this provision further supports considerable circumscription of the state's power. This limitation rests upon the presumption that equalizing the demands from private education to those in public schools would render the Institutional Parental Right meaningless and grant the state excessive control over education leaving the parents without a viable alternative to the state's educational narrative and agenda. Accordingly, the literature suggests the extent of the said minimum standards must be severely restricted. 
Thus, Beiter claims private education to be 'broadly equivalent' to the public curriculum, 'but must leave the determination of content and methods largely to private schools themselves'; Coomans sees it to be 'evident that such standards may not frustrate' the freedom to establish and direct non-state educational institutions; and Nowak asserts that within the goals of education already set in international law, private schools are free to develop 'their own curricula, to apply specific admissibility criteria (even if these would be considered discriminatory in public schools), and teaching methods' ${ }^{84}$ These views, particularly the latter, essentially mean that the power to impose 'minimum standards' is limited to the educational goals of international law and does not allow the state to dictate any additional criteria. Now, while this approach is certainly warranted given the above considerations, it suffers from an interpretive difficulty. Since private schools are anyway obligated to follow the educational goals set in international law, the provision regarding 'minimum educational standards' becomes redundant.

In order to settle this issue without collapsing the Institutional Parental Right into its substantive counterpart, the "minimum educational standards' requirement may be interpreted as allowing the state to impose on private schools not only the international goals of education - which, as mentioned, coincide to an extent with the state's interest in nurturing in children such civic virtues as effective participation in society or tolerance - but also regulatory requirements, concerning school registration, safety, health, teachers' qualifications, maximum number of students, student-teacher ratio, and other like technical standards. These standards can be characterized as providing the minimum necessary conditions for any school environment or curriculum and thus would not frustrate the Parental Right even in the context of private education.

\section{Conclusion}

The scope of the Parental Right encompasses education in public schools, in private institutions, and at home. The Right therefore is implemented to varying degrees in accordance with the type of education parents have chosen for the child, but all its aspects nevertheless share several robust 
standards. Beyond the basic principle that the Parental Right does not extend to completely denying the child's education, it is always subject to the premises that education must be directed to accomplish the core aims of education and fulfill the minimal educational standards set by the state.

The article has set forth that the Parental Right always requires a narrow interpretation of the first two limitations so as to maximally accommodate potential parental views. Thus, if a core educational aim suffers two or more meanings, one of which can accommodate the parents' views, then following the principle of 'consistent interpretation', this meaning should be chosen over others. On the other hand, if the aim clearly contradicts the parental preferences - for example if parents oppose the promotion of tolerance, respect of rights, or basic civic virtue - it must prevail and limit the scope of the Right. Similarly, the state power to dictate minimal standards in all types of education is limited to the administrative regulation of educational conditions - like safety or hygiene - and does not include the imposition of substantive norms beyond the core educational aims.

Furthermore, the scope of the Parental Right always allows parents to have partial control over the fundamental values taught to their children. The Substantive Parental Right - which, as the article argues, extends to public, private and home education, and which authorizes parents to ensure that the basic values constituting their child's education accord with their own convictions - is being interpreted increasingly broadly as relevant to practically all aspects of education that conflict with deeply held parental beliefs. It applies not only to matters of religion or morals, but also to linguistic preferences; it concerns contents that have only incidental disagreement with the parental views; and includes not only the contents and methods of education but also the school organization.

The actual implementation of the Substantive Parental Right, however, reveals the main differences between the scope of parental prerogatives in public and private education. In the public-school system, the Right is abrogated if the educational contents to which the parents are opposed are taught in a neutral and non-indoctrinating manner. And even if the parental convictions are found to be unlawfully disregarded in the public school, the Substantive Parental Right, save for extreme circumstances, entitles parents only to exclude their child from being exposed to the problematic contents, but not to include contents based on their convictions in the school curriculum (given the Parental Right is not a positive claim, see above, Section I). 
These constraints do not apply in the alternatives to state education, as they are annulled by the institutional aspects of the Parental Right. These additional aspects grant parents the prerogative to bias their children in favor of their own religious and moral beliefs without having to expose them to the views promoted by the state or other entities, as long as this narrow education does not violate the abovementioned human rights norms. The parents - and in case the child attends a private school, also the school officials - are, however, subjected to supervision by the state, which is obligated to ensure they pursue the core aims of education and fulfill the state's own educational standards.

\section{BIBLIOGRAPHY}

Beiter, Klaus Dieter. The Protection of the Right to Education by International Law (Martinus Nijhoff 2006).

Cohen-Eliya, Moshe and Hammer, Yoav. 'An Argument from Democracy against School Choice: A Critique of Zelman v. Simmons-Harris’ (2003) 49 Loy L Rev 859.

Coomans, Fons. 'Content and Scope of the Right to Education as a Human Right and Obstacles to Its Realization' in Yvonne Donders and Vladimir Volodin (eds.), Human Rights in Education, Science, and Culture: Legal Developments and Challenges (Ashgate 2007), 183-229.

Craven, Matthew C.R. The International Covenant on Economic, Social, and Cultural Rights: A Perspective on Its Development (Oxford University Press 1998).

Detrick, Sharon. A Commentary on the United Nations Convention on the Rights of the Child (Martinus Nijhoff 1999).

Dwyer, James G. Religious Schools v. Children's Rights (Cornell University Press 1998).

Gilles, Stephen G. 'On Educating Children: A Parentalist Manifesto' (1996) 63 U Chi L Rev 937.

Gunn, T. Jeremy. 'The Complexity of Religion and the Definition of Religion in International Law Conference: Religion, Democracy, \& Human Rights' (2003) 16 Harv Hum Rts J 189.

International Labour Standards Department. Indigenous and Tribal Peoples' Rights in Practice: A Guide to ILO Convention No. 169 (ILO 2009).

Judge, Harry. 'Faith-Based Schools and State Funding: A Partial Argument' (2001) 27 Oxf Rev Educ 463.

Levine, Samuel J. 'A Critique of Hobby Lobby and the Supreme Court's Hands-off Approach to Religion Essays' (2015) 91 Notre Dame L Rev Online 26.

Levinson, Meira. The Demands of Liberal Education (Oxford University Press 2002).

Mowbray, Jacqueline. Linguistic Justice: International Law and Language Policy (Oxford University Press 2012). 
Nowak, Manfred. 'The Right to Education' in Asbjorn Eide et al. (eds.), Economic Social and Cultural Rights: A Textbook (2nd rev edn, Martinus Nijhoff 2001), 245-271.

Nowak, Manfred. U.N. Covenant on Civil and Political Rights: CCPR Commentary (2nd edn, NP Engel 2005).

Paquette, Jerry. 'Public Funding for "Private" Education: The Equity Challenge of Enhanced Choice' (2005) 111 Am J Educ 568.

Saul, Ben, et al. The International Covenant on Economic, Social and Cultural Rights: Commentary, Cases, and Materials (Oxford University Press 2014).

Savigny, Friedrich Karl von. System of the Modern Roman Law (William Holloway tr, J. Higginbotham 1867).

Schabas, William A. The Universal Declaration of Human Rights: The Travaux Préparatoires (Cambridge University Press 2013).

Thornberry, Patrick. International Law and the Rights of Minorities (Clarendon Press 1993).

Wildhaber, Luzius. 'Right to Education and Parental Rights' in Ronald St. J. Macdonald et al. (eds.), The European System for the Protection of Human Rights (Kluwer Law International 1993), 531-551. 